\title{
EFFECTS OF TOTAL QUALITY MANAGEMENT (TQM) ON FINANCIAL AND NON-FINANCIAL PERFORMANCE: EVIDENCE FROM HIGHER EDUCATIONAL SECTOR OF PAKISTAN
}

Tehmeena Shafqat ${ }^{1}$, Rabia Mushtaq ${ }^{2}$, Zonaib Tahir ${ }^{3}$, Wasim Abbas Shaheen ${ }^{4}$

${ }^{1 *} \mathrm{Ph} . D .$, Scholar, Quaid-i-Azam School of Management Sciences, Quaid-i-Azam University, Islamabad, Pakistan;
${ }^{2,3,4}$ Assistant Professor, Quaid-i-Azam School of Management Sciences, Quaid-i-Azam University, Islamabad, Pakistan.
Email: " tehmeena.shafqat@ yahoo.com

Article History: Received on $10^{\text {th }}$ May 2021, Revised on $12^{\text {th }}$ June 2021, Published on $19^{\text {th }}$ June 2021

\begin{abstract}
Purpose: This research explores the causal linkage between TQM and financial performance or non-financial performance within the higher education sector of Pakistan. In this regard, the link between each element of total quality management, including tangibles, reliability, responsiveness, assurance, and empathy, was explored and empirically analyzed concerning financial and non-financial performance.
\end{abstract}

Methodology: The regression and correlation statistical measures, using SPSS version 20.0, were used to study the linkage of TQM with financial and non-financial performance. The study utilized a quantitative research approach for data collection purposes, and data was gathered from 220 employees of well-established higher educational institutes of Islamabad and Rawalpindi with the help of a directly administered survey approach.

Results: The results support the causal linkage between TQM and financial or non-financial performance. The findings indicate that TQM has a significant positive link with the financial and non-financial performance of service organizations within the higher education sector of Pakistan.

Applications of this study: The higher education industry is the backbone of every nation, especially the developing countries. The higher education sector of developing countries, such as Pakistan, has been facing issues of quality, and hence the implementation of TQM practices can have a considerable effect on its improvement. This study provides valued insights for higher education practitioners to revise policies for the positive growth and development of this sector.

The Novelty of this study: The contribution of this research is the investigation of TQM practices on financial and nonfinancial performance of higher educational institutes of a developing nation, i.e. Pakistan, where it is relatively a new concept. It was found that TQM practices have a significant impact on financial and non-financial performance.

Keywords: Total Quality Management, Tangibles, Reliability, Responsiveness, Assurance, Empathy, Financial Performance, Non-Financial Performance.

\section{INTRODUCTION}

Total quality management has been characterized as a significant aspect of operations management research that has captured the attention of researchers mainly since the last decade. According to Arokiasamy \& Tat (2014), the concept of TQM represents practices and measures utilized to reduce or eliminate production process variations as well as positively improving the systems of service delivery to achieve continuous improvements in quality, reliability, and efficiency. It focuses on the creation of an organizational environment where the employees are committed to enhancing the products and services quality for corporate consumers on a continual basis (Sila, 2018; Shafiq et al., 2017). This improvement lies in the process, products, and people working within an organization. In the past, most of the research attention has been focused on examining the influence of TQM practices on firm performance. Mixed results have been found, such as some of the researchers report a strong link (Singh et al., 2018; Asif et al., 2013), while others indicate medium or weak link in the execution of TQM practices and firms performance (Akgün et al., 2014). The impact of TQM on performance is measured in two ways; some of the researchers measure it in purely financial terms of ROI and profit (Qasrawi et al., 2017; Nicolau \& Sellers, 2010).

In contrast, others have measured it in non-financial terms such as satisfaction of consumers, improvement in process, and employee satisfaction (Zwain et al., 2017; Martínez-Costa et al., 2009). It has also been argued that the strength of this relationship depends on some other factors such as the social, economic, and cultural situations facing the organization (Sila, 2018; Kull \& Wacker, 2010). The research has shown that the results of implementing TQM practices in Asian nations were different from that of the implementation in western countries. Thus, it is argued that despite the linkage between TQM and the performance model has been investigated; it is imperative to re-investigate it in the context of each specific nation (Shafiq et al., 2017; Sila \& Ebrahimpour, 2005). This signifies the importance of investigating TQM practices in the context of Pakistan, where it is relatively a new concept (Chaudhry et al., 2018).

Besides this, the higher education industry is the backbone of every nation, specifically the developing countries. The importance of implementing TQM systems in manufacturing sectors (Singh et al., 2018; Shafiq et al., 2017) and the banking sector has been studied (Sit et al., 2010), but its implementation in the higher education system still calls for 
further attention. The higher education sector of Pakistan is facing issues of quality as it is ranked as one of the lowest quality education systems all around the world. The implementation of TQM practices can have a considerable effect on its improvement (Chaudhry et al., 2018). Further, only six universities of Pakistan have been included in the 800 universities list by the QS ranking system. The government is reducing the availability of public funding for universities, and now they have to rely on their funds generated by the student enrollment. The competition within the higher education sector is rapidly increasing, which makes it difficult to survive.

Further, the staff-to-student ratio is decreasing, and the service level demands are growing. All these issues are driving the higher education institutes to implement the proper quality standards to capture a significant student base, to improve their profit levels along with the attainment of positive satisfaction level among students efficiently and effectively (Chaudhry et al., 2018; Baig et al., 2015).

Therefore, the current research aims to study the effects of TQM on financial performance and non-financial performance within the higher education sector of Pakistan to deliver some valued insights for higher education practitioners to revise policies for positive growth and development of this sector.

\section{LITERATURE REVIEW}

\section{Total quality management (TQM)}

Garcia-Bernal \& Ramirez-Aleson (2017) explained that the concept of TQM represents all practices and measures utilized to reduce and eliminate the production processes variations within systems of service delivery for achieving continuous improvements in quality, reliability, and efficiency. It takes into account improvements in all areas of business and ultimately maintaining the level of progress at all levels. Further, it concentrates on customers by taking care of their needs and wants. Besides this, the employees are the primary deliverables of service, so they are also an essential part of the TQM system. Hence it is a fundamental approach to managing and improving the flexibility, effectiveness, and competitiveness of the whole business (Zhang et al., 2014). Zabadi (2013) reported that the appropriate execution of TQM practices in higher education institutes significantly influences the overall performance.

Moreover, the effective implementation of a service sector organization can be assessed by the SERVQUAL model, and the model is particularly applicable in the higher education sector too. SERVQUAL model highlights five dimensions of effective service performance, including tangibles, reliability, empathy, responsiveness, and assurance. According to the SERVQUAL model, services are "Tangible" in terms of the physical environment, infrastructure, employees, and material of communication. The service should be "Reliable" such that the employees are in a position to deliver the service accurately. The employees must be quick in giving "Response" and offer prompt service. The employees must submit the "Assurance" that they are able and knowledgeable about the delivery of service and have good manners and courtesy. Lastly, effective delivery of services requires an employee to be "Empathetic" to pay individual attention to the consumers and deal with a high level of care (Shafiq et al., 2017; Asif et al., 2013). This study examines each dimension of total quality management, including tangible, responsiveness, reliability, assurance, and empathy with financial and non-financial performance.

\section{Financial and non-financial performance}

According to Nicolau \& Sellers (2010), organizational performance denotes comparing the actual results with the set objectives. The influence of TQM on performance can be calculated in two ways; some of the researchers measured it in purely financial terms such as ROI and profit (Nicolau \& Sellers, 2010). But others have measured it in non-financial terms like customer satisfaction, enhancement in processes, employee satisfaction, and human resource performance (Martinez-Costa et al., 2009). The past studies in the area highlighted the importance of financial measures but reported them as insufficient for a complete performance evaluation system. The non-financial performance measures need to consider providing valuable insights. According to Raphael \& Man (2013), different organizational activities jointly results in firm value through which the critical success factors of service organization can be promoted in the marketplace. These factors involve customer satisfaction, quality, and productivity, and so on.

Furthermore, Qasrawi et al., (2017) also reported that future financial performance could be improved by focusing on these critical factors. As a whole, the long-term consequences of organizational activities cannot be entirely reflected by solely focusing on financial measures like ROI, operating income, etc. As a result, the non-financial performance measures are considered by organizations that complement the financial performance measure hence representing the primary value-creating organizational activities. Moreover, empirical research connecting service quality and nonfinancial performance is also limited (Feng et al., 2006). Hence valuable insights can be gained by investigating the effects of TQM on the account of the organization both in financial and non-financial terms.

\section{TQM and financial performance}

Shafiq et al. (2017) stated that adequate application of TQM practices within the educational sector could significantly impact the overall performance of higher educational institutes. Moreover, Gars-Bernal \& Ramirez-Aleson (2015) also noted a positive association between practical quality management approaches and the firm performance in both manufacturing and service organizations. The quality assurance managers' effective quality management system 
positively influences the business bottom line in the industrial and service sectors. The quality procedure enhances the operational productivity of institutes, which translates into positive effects on profits, and satisfaction of customers and stakeholders (Senthilkumar \& Arulraj, 2011). Besides this, Shafiq et al. (2017) reported that when staff is empathetic, able, and responsive, and educational institutes have a good environment and infrastructure, it will have a positive influence upon the performance of the academic service sector in terms of student satisfaction and financial performance.

Tangibles and financial performance: Tangible denotes organization equipment, physical appearance, facilities, and workplace environment. Prior researchers have argued that these tangibles have a significant influence on organizational overall financial performance. Alatrash (2018) reported that tangible goods, a comfortable workplace environment, convenience in using corporate equipment and appropriate training of new technological equipment have a positive influence on corporate financial performance. Furthermore, Sila (2018) stated that a positive relationship exists between workplace environment, managerial employees, tangible goods, level of comfortableness, and company performance in both financial and non-financial terms.

Reliability and financial performance: Reliability is another fundamental dimension of total quality management that largely influences an organizational financial performance in the long run. It can be determined as the accuracy of an organization regarding the promises which they have made with their employees during their recruitment process. The employees' skill enhancement practices, feedback system, understanding of employee needs, equal chances of opportunity to employees, and service provisions are essential elements, which have a significant effect on employees' performance, and eventually, positive levels of employees version translates into positive organizational financial performance (Banerjee \& Sah, 2012). Moreover, Mohammad et al. (2011) have found reliability as a significant corporate reputation element and the most reliable service quality indicator, which significantly influences employees overall performance. Hence when organizations provide their employees supportive and loyal service environment, by fulfilling their expectations and demands, employees will have more confidence in their organization and work hard, which achieves positive organizational performance.

Responsiveness and financial performance: The research studies in the area of TQM have indicated responsiveness as a significant element of service quality which results in positive satisfaction levels among the customer base (Al-Azzam, 2015). Responsiveness can be defined as management's efficient response towards their employees in solving their queries and eventually helping them solve their customer base problems and complaints to achieve set targets and improved organizational performance levels (Gupta \& Agarwal, 2013). Baig et al. (2015) also reported that a higher level of employee responsiveness within higher educational institutes, towards student problems and queries, enables the service provider to sustain a satisfied customer base for the long run. Besides this, Qasrawi et al. (2017) have found that significant factors within higher educational institutes such as promptness of responses from the supervisor, sound feedback system, supporting behaviour of top management, and timely delivery have the power to influence employee performance, which in turn strongly affects the overall performance of the whole organization (Karim \& Chowdhury, 2014).

Assurance and financial performance: According to Sila (2018), focus on several factors, such as comfort in the provision of salaries, financial advice, easy access supervisor, experienced and knowledgeable management teams within higher educational institutes, increase the satisfaction level of their workforce and help them to become more focused on their work activities, which enable the organization to get a positive level of financial and non-financial performance. Furthermore, Singh et al. (2018) reported that the delivery of precise knowledge, along with the establishment of appropriate standards of educational processes, significantly influences customer satisfaction levels. The engagement of employees in courtesy practices provides customers with the assurance that their problems will be solved by the respective service organization, which positively influences organizational performance in the context of both private and public sector service organizations (Sila 2018; Banerjee \& Sah, 2012).

Empathy and financial performance: Empathy is basically when an organization is taking care of its employees by giving individual attention. Prior researches have stated that the empathy of organization towards their employees has a significant influence on organizational performance. Empathy explains that employees of the organization are unique as they are helping the organization to perform their routine tasks, and make the organization able to get higher financial and non-financial performance for the long term (Shafiq et al., 2017). The element of empathy facilitates educational service providers to offer customized care to students that help them in the achievement of their goals ultimately translates into positive satisfaction levels of students (Singh et al., 2018). Past studies in the area of TQM indicated that the empathy aspect of TQM not only facilitates the service organizations to achieve a competitive edge but also results in greater customer satisfaction (Mohammad et al., 2011), which eventually translates into a positive level of financial and non-financial performance.

\section{TQM and non-financial performance}

Agbor (2011) stated that the purchase decisions of customers are highly dependent upon their evaluation of organizational marketing efforts. Whereas customer satisfaction is positively associated with products and services evaluations by customers at the marketplace by analyzing either the utilized products or services meet customer 
expectations or not (Shafiq et al., 2017). A plethora of studies examines the association between service quality and customer satisfaction. To effectively manage the existing competition of rival universities in the marketplace, institutions in the higher education sector need to focus on enhancing the total management practices within their institutes by concentrating on five integral components of total quality management, i.e. tangibles, reliability, empathy, responsiveness, and assurance (Zwain et al. 2017). Hanaysha et al. (2011) found that the five major elements of TQM, including tangibles, reliability, empathy, responsiveness, and assurance, significantly influence the satisfaction level of the student within higher education institutes. Moreover, Khan et al. (2011) also reported a positive linkage among tangibles, reliability, empathy, responsiveness, assurance, and student satisfaction, which in turn significantly and positively influences performance levels of higher education institutes.

Tangibles and non-financial performance: The tangibles aspect of TQM facilitates customers to assess the services provided by the organization before its utilization (Zwain et al., 2017). In the service industry, tangibility is termed as a vital aspect of TQM that influences customer satisfaction largely. Singh et al. (2018) reported that various tangible factors of service, including its physical facilities, technological equipment and materials adjacent to them, and skills and appearances of the workforce, have a significant and positive impact upon the level of customer satisfaction. They stated that products of the education sector are intangible: as a result, tangible factors of service organizations contribute towards their student satisfaction.

Furthermore, Arokiasamy \& Tat (2014) also stated that customer satisfaction depends on tangibles such as technological equipment and organizational workforce. The tangibles lead an organization towards differentiation, sustainable growth as well as positive levels of satisfaction among the customer base. As a whole, the tangible aspect of service quality within the higher education sector results in greater student satisfaction and organizational profitability that translates into long-term sustainable relationships among both parties (Sila, 2018; Shafiq et al., 2017).

Reliability and non-financial performance: Reliability signifies that the customers of the service organization receive the service provided as promised to them. In other words, reliability refers to either the customer problems are addressed effectively, and their records are maintained appropriately or not by service organizations (Khan \& Fasih, 2014). According to Singh et al. (2018), the reliability dimension is another essential aspect of TQM in the higher education sector because any mistake on behalf of the service provider requires corrective actions quickly to regain the students' trust and confidence. Moreover, those service organizations are preferred by customers that are capable of keeping and executing their organizational promises. Previous studies in the area of TQM also indicated that the level of customer satisfaction could be enhanced by focusing on the reliability component of TQM (Zwain et al., 2017). According to Kashif et al. (2015), reliability is a significant TQM component that enables the organization to attain positive customer satisfaction and performance levels in the marketplace.

Responsiveness and non-financial performance: The element of responsiveness in TQM represents that students are provided with quality services, the higher educational institutions' personnel are willing to serve students, and any problem faced by students on behalf of service organization will be solved on an immediate basis (Zwain et al., 2017). The past studies in TQM have shown that responsiveness is also a vital element of service quality which results in positive levels of satisfaction among customers (Al-Azzam, 2015). Moreover, a high level of employee responsiveness, within higher educational institutes, towards students' problems and queries enables the service provider to sustain a satisfied customer base for the long run. In addition to this, the needs of target customers should be understood by service providers, along with providence of appropriate orientation to the workforce, for frequent student dealing, can enable the service organization to achieve student satisfaction and overall organizational success at the marketplace (Singh et al., 2018; Shafiq et al., 2017).

Assurance and non-financial performance: Assurance is mainly a representation of knowledge and courtesy possessed by the organizational employees, which facilitate the service organization to achieve the trust and confidence of customers (Khan \& Fasih, 2014). Zwain et al. (2017) reported that the delivery of precise knowledge, along with the establishment of appropriate standards of educational processes, significantly influences customer satisfaction levels. Moreover, the engagement of employees in courtesy practices provides customers with the assurance that their problems will be solved by the respective service organization. The component of assurance, including employee knowledge and courtesy, helps in developing trust among the customer base. As a result, the positive level of trust among customers regarding organizational offerings influences customer satisfaction levels positively. Hence the customer trust in the organization translates into a positive level of customer satisfaction and purchase intentions (Sila, 2018; Al-Azzam. 2015).

Empathy and non-financial performance: In higher educational institutions, the empathy can be referred to as a providence of attention that is individual towards every student. The element of empathy facilitates the academic service providers to offer customized care to students that help them in the achievement of their goals and ultimately translates into positive satisfaction levels of students (Singh et al., 2018; Zwain et al., 2017). According to Qasrawi et al. (2017), empathy has a significant and positive association with customer satisfaction. The employee's empathetic behaviour results in positive attitudes of customers towards service organization that translates into positive organizational growth and performance. As a whole, the research in the area of TQM reported that empathy influences student satisfaction positively and enables the service providers to build a loyal consumer base (Al-Azzam, 2015). The conceptual 
framework for TQM, financial performance, and non-financial performance is presented in Figure 1. It indicates that TQM comprises of five dimensions, including tangibles, reliability, responsiveness, assurance, and empathy as an independent variable, and financial performance and non-financial performance as a dependent variable. The following hypotheses are derived for the present study.

Hypothesis 1: Total quality management has a positive influence on the financial performance of higher education institutes in Pakistan.

Hypothesis 1a: A positive association exists between tangibles and the financial performance of higher education institutes in Pakistan.

Hypothesis 1b: A positive association exists between reliability and the financial performance of higher education institutes in Pakistan.

Hypothesis 1c: A positive association exists between responsiveness and the financial performance of higher education institutes in Pakistan.

Hypothesis 1d: A positive association exists between assurance and the financial performance of higher education institutes in Pakistan.

Hypothesis 1e: A positive association exists between empathy and the financial performance of higher education institutes in Pakistan.

Hypothesis 2: Total quality management has a positive influence on the non-financial performance of higher education institutes in Pakistan.

Hypothesis 2a: A positive association exists between tangibles and the non-financial performance of higher education institutes in Pakistan.

Hypothesis 2b: A positive association exists between reliability and the non-financial performance of higher education institutes in Pakistan.

Hypothesis 2c: A positive association exists between responsiveness and the non-financial performance of higher education institutes in Pakistan.

Hypothesis 2d: A positive association exists between assurance and the non-financial performance of higher education institutes in Pakistan.

Hypothesis 2e: A positive association exists between empathy and the non-financial performance of higher education institutes in Pakistan.

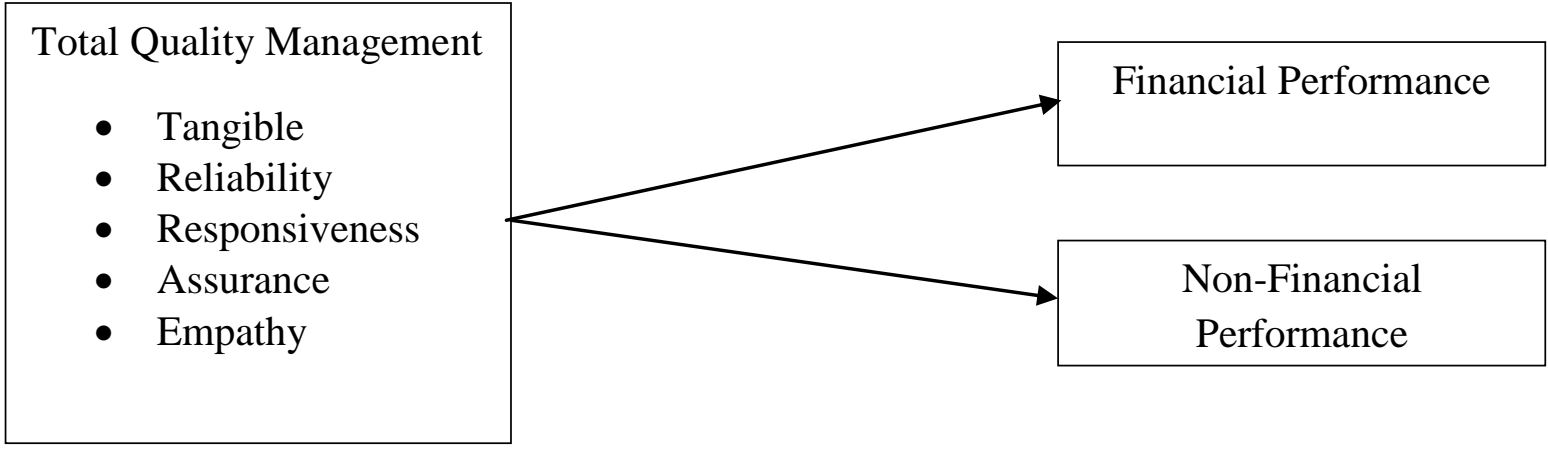

Figure 1: Conceptual Framework

\section{RESEARCH METHODS}

\section{Study design}

The quantitative research approach was followed, as it facilitates the researcher to explain the association between variables effectively. The fundamental rationale of current research is to study the effects of TQM on the financial and non-financial performance of higher educational institutes in Pakistan. The patterns and relationship of this study have primarily supported investigating of the causal linkage among the dimensions of TQM and organizational financial and non-financial performance.

The survey strategy has been characterized as one of the most appropriate data collection tools in academic research, which helps in the efficient and effective selection of study samples. It enables the researcher to obtain opinions, suggestions, norms, and values of participants with great care. Furthermore, the questionnaire is the primary instrument of the survey approach (Fowler, 2013). Hence the survey approach was followed in this study for data collection purposes from the study population in the empirical form, which signifies primary data collection and analysis. The 
questionnaires were directly administered to upper and middle management, specifically the administrative staff, to study the influence of TQM on financial and non-financial performance in the higher education sector.

\section{Population and sampling}

This study focused on investigating the causal linkage between TQM and financial or non-financial performance within the higher education institutes of Pakistan. Hence administrative staff of public and private sector universities operating in Pakistan was the target population. The whole population cannot be involved in the conducted study, so a sample was chosen to complete the survey. The convenience sampling technique was employed, and the data was gathered from administrative employees of public and private sector universities, operating in Islamabad and Rawalpindi, including Quaid-i-Azam University, COMSATS University, National University of Modern Languages (NUML), International Islamic University (IIUI), PMAS, Arid Agriculture University, and Fatima Jinnah Women University. In total, 250 questionnaires were directed, but 220 respondents replied completely, which denotes a response rate of $88 \%$ for this study.

\section{Research instrument and measures}

The Likert scale was primarily utilized to assess the variables under study. Furthermore, a five-point Likert scale was followed to gather the responses to a scale ranging between "Strongly Agree" (1) to "Strongly Disagree" (5). A five-item scale proposed by Santos et al. (2015) was used to measure tangibles. A five-item scale proposed by Shahin et al., (2014) was used to measure reliability. A five-item scale proposed by Ozretic-Dosen \& Zizak (2015) was used to measure empathy. Further, a five-item scale proposed by Woods \& Miles (2014) was used to measure responsiveness and a fiveitem scale proposed by Zhang et al. (2014) was used to measure assurance. Financial performance was assessed using a five-item scale developed by Ben et al. (2014), while non-financial performance was assessed following a five-item scale proposed by Feng et al. (2006).

\section{Data analysis}

The statistical tests, including regression and correlation analyses, were applied to data using SPSS version 20.0. Regression analysis demonstrates the dependence of financial and non-financial performance on total quality management, which is calculated by following the general equation of regression model, i.e. $Y=\alpha+\beta X$, where ' $Y$ ' is dependent variable, i.e. financial performance and non-financial performance and ' $X$ ' is the independent variable, i.e. total quality management (Cohen et al., 2014). The other applied analysis in this study was correlation analysis which examines the extent of association between TQM and financial or non-financial performance. In correlation analysis, Pearson's correlation coefficient was followed.

\section{RESULTS AND DISCUSSION}

\section{Demographics analysis}

The study explores the association between TQM and financial performance and non-financial performance. Data was gathered from employees of various higher educational institutions of Rawalpindi and Islamabad. The demographics statistics revealed that the majority of respondents were male (78.2\%). The sample age distribution specified that majority of respondents were from the age group of $30-39$ years $(65.5 \%)$. Further, it was found that the majority of participants who contributed to this study holds MPhil/MS degree as their highest qualification (55.5\%). Besides, the majority of participants who contributed to this study possessed $2-4$ years of working experience (32.3\%). Table 1 exhibits the outcome of demographic analysis for this study concerning gender, age, educational level, and working experience.

Table 1: Demographics of Sample Data

\begin{tabular}{llll}
\hline Questions & Options & F & Percent \\
\hline Gender & Male & 172 & 78.2 \\
\hline Age & Female & 48 & 21.8 \\
\hline & 20-29 Years & 66 & 30.0 \\
\hline & 30 - 39 Years & 144 & 65.5 \\
\hline & $40-49$ Years & 8 & 3.6 \\
\hline \multirow{2}{*}{ Educational Level } & 50 and Above Years & 2 & 0.9 \\
& MPhil/MS & 122 & 55.5 \\
\hline & Masters & 76 & 34.5 \\
\hline & Bachelors & 20 & 9.1 \\
\hline Working Experience & Intermediate & 2 & 0.9 \\
\hline & 2 Year and below & 31 & 14.1 \\
\hline & 5 Year - 4 Years & 71 & 32.3 \\
\hline
\end{tabular}




\begin{tabular}{lll}
\hline 8 Years - 10Years & 42 & 19.1 \\
\hline 10 Years and above & 8 & 3.6 \\
\hline
\end{tabular}

\section{Correlation and reliability analysis}

To examine the strength of the relationship among variables under study, including TQM and financial or non-financial performance, correlation analysis was conducted. Table 2 contains the correlation matrix where TQM and financial or non-financial performance are correlated with each other.

Table 2: Correlation and Reliability Analysis

\begin{tabular}{|c|c|c|c|c|c|c|c|}
\hline & TNG & REL & RES & ASR & EMP & FP & NFP \\
\hline TNG & $1(.781)$ & $.620 * *$ & $.479 * *$ & $.434 * *$ & $.612 * *$ & $.375 * *$ & $.355 * *$ \\
\hline REL & $.620 * *$ & $1(.729)$ & $.622 * *$ & $.665 * *$ & $.642 * *$ & $.541 * *$ & $.539 * *$ \\
\hline RES & $.479 * *$ & $.622 * *$ & $1(.747)$ & $.696^{* *}$ & $.558 * *$ & $.605^{* *}$ & $.523 * *$ \\
\hline ASR & $.434 * *$ & $.665^{* *}$ & $.696 * *$ & $1(.766)$ & $.579 * *$ & $.611^{* * *}$ & $.637 * *$ \\
\hline EMP & $.612 * *$ & $.642 * *$ & $.558 * *$ & $.579 * *$ & $1(.738)$ & $.506^{* *}$ & $.542 * *$ \\
\hline FP & $.375 * *$ & $.541 * *$ & $.605^{* *}$ & $.611 * *$ & $.506 * *$ & $1(.747)$ & $.627 * *$ \\
\hline NFP & $.355^{* * *}$ & $.539 * *$ & $.523 * *$ & $.637 * *$ & $.542 * *$ & $.627 * *$ & $1(.718)$ \\
\hline
\end{tabular}

**Correlation is significant at 0.01

The result of the correlation matrix represents that reliability has a moderate positive relationship with tangibles (.620). Responsiveness has a moderate positive relationship with tangibles (.479) as well as with reliability (.622). Assurance has a weak positive relationship with tangibles (.434), a moderate positive relationship with reliability (.665), and responsiveness (.696). Moreover, it has been found that empathy has a moderate positive relationship with tangibles (.612), reliability (.642), responsiveness (.558), and assurance (.579). The financial performance has a weak positive relationship with tangible (.375) and a moderate positive relationship with reliability (.541), responsiveness (.605), assurance (.611), and empathy (.506). The non-financial performance is weakly positively correlated with tangibles (.355) and moderately positively correlated with reliability (.539), responsiveness (.523), assurance (.637), empathy (.542), and financial performance (.627). The results of the correlation matrix conclude that the higher the total quality management within organizations, the higher will be the financial and non-financial performance. Further, the outcomes of reliability in parenthesis represent adequate consistency and reliability of the scale used in the current study.

\section{Regression analysis}

The quantitative solution of research questions is also required along with a qualitative basis (Cohen et al., 2014). In this respect, the regression analysis is particularly significant in this study where financial performance and non-financial performance are measured as dependent factors depending upon one independent factor, i.e. TQM. Based on this, the general equations of the multiple regression models are stated below, where FP denotes financial performance, and NFP denotes non-financial performance as dependent factors. Total quality management as an independent factor includes tangibles, reliability, responsiveness, assurance, and empathy.

Financial Performance $=\alpha+\beta_{1}$ (Tangible) $+\beta_{2}$ (Reliability) $+\beta_{3}$ (Responsiveness) $+\beta_{4}$ (Assurance) $+\beta_{5}$ (Empathy) $+\mathrm{e}$ ..................................... Model 1

Non-Financial Performance $=\alpha+\beta_{1}($ Tangible $)+\beta_{2}($ Reliability $)+\beta_{3}($ Responsiveness $)+\beta_{4}($ Assurance $)+\beta_{5}($ Empathy $)+$ e .................................... Model 2

Effect of TQM on financial performance. Table 3 shows regression results of the influence of TQM on financial performance.

Table 3: TQM Effect on Financial Performance

\begin{tabular}{clcc}
\hline Model & Independent Variables & Standardized Coefficient ( $\beta$ ) & P-value \\
\hline 1 & Constant & 68.02 & .000 \\
\hline & Tangibles & 0.360 & .000 \\
\hline & Reliability & 0.121 & .001 \\
\hline & Responsiveness & 0.283 & .000 \\
\hline Assurance & 0.270 & .006 \\
\hline Empathy & 0.136 & .004 \\
\hline
\end{tabular}

Dependent factor: Financial Performance; at significance level: $0.01 *$

The regression analysis results denote that tangibles $(\beta=.360, \mathrm{p}=.000)$ is significantly and positively associated with financial performance, and the results imply that the hypothesis 1 (a) of this study has been accepted. The results show that reliability $(\beta=.121, \mathrm{p}=.001)$ is significantly and positively associated with financial performance, and results imply that the hypothesis $1(\mathrm{~b})$ has been accepted. It was found that responsiveness $(\beta=.283, \mathrm{p}=.000)$ has a significant 
and positive association with financial performance and the results imply the hypothesis 1 (c) has been accepted. The results of Assurance also disclose $(\beta=.270, \mathrm{p}=.006)$ a significant and positive association between assurance and financial performance, and results imply that the hypothesis 1 (d) has been accepted. Further, the outcomes of regression analysis also revealed that Empathy $(\beta=.136, \mathrm{p}=.004)$ has a significant and positive association with Financial Performance. Hence hypothesis 1(e) of the current study has also been accepted. This model implies that financial performance is significantly dependent upon total quality management practices of the higher education institutions within the education industry.

Effect of TQM on non-financial performance: Table 4 indicates the regression results of the effect of TQM on nonfinancial performance.

Table 4: TQM Effect on Non-Financial Performance

\begin{tabular}{llcc}
\hline Model & Independent Variables & Standardized Coefficient $(\boldsymbol{\beta})$ & P-value \\
\hline 2 & Constant & 68.02 & .000 \\
\hline Tangibles & 0.170 & .000 \\
\hline Reliability & 0.140 & .000 \\
\hline Responsiveness & 0.711 & .003 \\
\hline Assurance & 0.402 & .000 \\
\hline Empathy & 0.238 & .001 \\
\hline
\end{tabular}

Dependent factor: Non-Financial Performance; at significance level: $0.01 *$

It is evident from the regression analysis that tangibles $(\beta=.170, \mathrm{p}=.000)$ is significantly and positively associated with non-financial performance, and the results imply that the hypothesis 2(a) of the present study has been accepted. The results show that the reliability $(\beta=.140, p=.000)$ is significantly and positively linked with non-financial performance, and the results imply that the hypothesis 2 (b) has been accepted. It was found that responsiveness $(\beta=.711, p=.003)$ also has a significant and positive association with non-financial performance, which implies that the hypothesis 2 (c) has been accepted. The results of assurance disclose $(\beta=.402, p=.000)$ a significant and positive association between assurance and non-financial performance, and the results imply that the hypothesis 2 (d) has been accepted. Further, the outcomes of regression analysis also revealed that empathy $(\beta=.238, \mathrm{p}=.001)$ is significantly and positively associated with non-financial performance, and hence hypothesis 2(e) of the current study has also been accepted. This model implies that the non-financial performance is significantly dependent upon total quality management practices of the higher education institutions within the education industry.

Regression model fit for TQM and financial or non-financial performance: Table 5 indicates the regression results of the effects of TQM on financial and non-financial performance.

Table 5: Summary of Models (Effects of Total Quality Management on Financial and Non-Financial Performance)

\begin{tabular}{llccc}
\hline Model & Independent factors & $\mathbf{R}^{\mathbf{2}}$ & Adjusted $\mathbf{R}^{2}$ & P-value \\
\hline $\mathbf{1}$ & TNG, REL, RES, ASR, EMP & .557 & .544 & .000 \\
\hline $\mathbf{2}$ & TNG, REL, RES, ASR, EMP & .661 & .648 & .000 \\
\hline
\end{tabular}

Dependent factor: Model 1 = Financial Performance, Model 2 = Non-Financial Performance

At significance level $0.01 *$

According to Saunders et al. (2012), $\mathrm{R}^{2}$ is the most appropriate statistical measure for comparing one or various regression models. Table 5 exhibits the results of regression model 1 and regression model 2 in terms of $\mathrm{R}^{2}$ and adjusted $\mathrm{R}^{2}$. Model 1, consisting of independent factors of TQM and financial performance, has a 0.544 adjusted $\mathrm{R}^{2}$ indicating $1 \%$ change in each dimension of total quality management produces a $54.4 \%$ change in financial performance. In contrast, Model 2, which is composed of independent factors of TQM and non-financial performance. has a 0.648 adjusted $\mathrm{R}^{2}$ value indicating $1 \%$ change in each dimension of total quality management produces a $64.8 \%$ change in non-financial performance.

\section{DISCUSSION}

It has been observed that with the effective implementation of TQM elements mentioned in our study, we can have positive impacts on the performance of the organizations in the education industry. Based on the SERVQUAL model, the finding of the current study suggests that firstly service organizations should focus on the tangible aspect of their service in terms of the physical environment, infrastructure, employees, and material of communication. Secondly, the service should be reliable such that the employees are in a position to deliver the service accurately. The employees must be quick in giving responses and offer prompt service. Further, the employees must offer the assurance that they are able and knowledgeable about the delivery of the service and have good manners and courtesy. Lastly, effective delivery of services requires an employee to be empathetic to pay individual attention to the consumers and deal with a high level of care. As a result, quality procedure enhances the operational productivity of service organizations, eventually having a 
positive influence on profits, customer satisfaction, and satisfaction levels of the entire stakeholder's involved, hence achieving positive performance levels for business in financial and non-financial terms. The same is the case with the higher education institutes that are facing the issues of poor quality and tough competition in the present era. The findings report that implementation of each element of the TQM system in this sector improves its functioning. Further, the findings of this study validate the prior studies in this area, indicating a positive association between TQM and financial or non-financial performance (e.g. Dieste et al., 2021; Yas et al., 2021; Batarfi, S., \& Attia, A., 2021; Singh et al., 2018; Sila, 2018; Shafiq et al., 2017; Zawin et al., 2017; Al-Azzam, 2015).

\section{CONCLUSION}

The fundamental rationale of the current study is to explore the impact of each element of TQM, including tangibles, reliability, responsiveness, assurance, and empathy, on the financial performance and non-financial performance of the higher education sector of Pakistan. The findings denote that the effective implementation of each mentioned element of TQM, within the higher education sector, significantly and positively influences the overall performance, including financial performance and non-financial performance of the organizations in the education industry. By making sure to have quality procedures in the organization contributes to the enhancement of the financial performance of the business also it creates efficiency in the organization's non-financial activities. It is also observed that it is now inevitable for all sorts of service organizations including the higher education sector to have quality procedures for all of their financial as well as non-financial activities by the way of Total Quality Management (TQM). The execution of TQM policies in the higher education sector will not only aid in maintaining competitiveness but will reduce the operational inefficiencies. Hence the higher education sector of Pakistan will be in a better position to utilize the funding for improvement of service delivery, which minimizes the cost of operations, meets the international demands and market criteria in educational settings, and hence satisfies all its stakeholders by expertly meeting their demands.

\section{MANAGERIAL IMPLICATIONS}

TQM has been characterized as the most significant determinant of achieving overall organizational success in the marketplace. For service organizations, the following is a list of implications based on findings of the present research study that need to be followed by service organizations to achieve higher organizational performance level:

- Firstly, all the channels, through which the service passes to reach the end-users, i.e. students, need to be monitored consistently by the managers or administrative staff within higher education institutes by focusing on capacity planning of the workforce to avoid any stressful situations in the marketplace.

- Secondly, the management should align the functions of all the departments within institutes, as well as the intercommunication should be organized among cross-functional departments on a regular and timely basis for improving TQM, organizational performance, and customer satisfaction within higher education institutes operating in Rawalpindi and Islamabad.

- Lastly, management must understand that the flaws or loopholes of the overall service system can be covered by good customer services that can facilitate the service organization to attain a positive level of financial and nonfinancial performance in the marketplace.

\section{RESEARCH LIMITATIONS AND FUTURE DIRECTIONS}

One of the limitations of the current study is its methodological design. Surveying a larger population and taking a broader context as a base will be helpful to improve the generalizability of results obtained from research. However, this was not possible due to certain constraints associated with time and cost. Further, the nature of this study is crosssectional, which restricts the researcher to gather the data at a single point in time only. Future studies can employ a longitudinal research design to explore the casual issues related to variables examined in this study in dynamic perspectives. Moreover, the future studies can also adopt the qualitative research paradigm, primarily for gaining an understanding of the concept of TQM more effectively and comprehensively. However, results obtained from the current study provide important data set for revising the total quality management practices within the education sector for improved organizational performance.

\section{AUTHORS CONTRIBUTION}

Tehmeena Shafqat: Identified major Research Gaps, Data Collection, Working on Literature Review and its writing, Abstract writing, review of the article after completion and correspondence with the journal.

Rabia Mushtaq: Develop conceptual theoretical framework, identified the significance of study, Develop hypotheses, Review of the article after completion and did proof reading.

Zonaib Tahir: Contributed in selecting analysis tools, data analysis and its interpretation.

Wasim Abbas Shaheen: Writing the discussion section on the results obtained and concluded the research paper. 


\section{REFERENCES}

1. Agbor, J. M. (2011). The relationship between customer satisfaction and service quality: A study of the service sectors in Ugaenda. Marketing Review, 2(1), 1-85.

2. Akgün, A. E., Ince, H., Imamoglu, S. Z., Keskin, H., \& Kocoglu, İ. (2014a). The mediator role of learning capability and business innovativeness between total quality management and financial performance. International Journal of Production Research, 52(3), 888-901. https://doi.org/10.1080/00207543.2013.843796

3. Alatrash, Z. (2018). Impact of using total quality management on the financial performance of companies listed on the Palestine Exchange. International Journal of Business and Economic Affairs, 3(6), 244-252. https://doi.org/10.24088/IJBEA-2018-36002

4. Al-Azzam , D. A. (2015). The impact of service quality dimensions on customer satisfaction: A field study of Arab Bank in Irbid city,. Jordan. European Journal of Business and Management, 7(15), 45-53.

5. Arokiasamy, A. R. A., \& Tat, H. H. (2014). Assessing the relationship between service quality and customer. Middle-East Journal of Scientific Research, 20(9), 1023-1030.

6. Asif, M., Awan, M. U., Khan, M. K., \& Ahmad, N. (2013). A model for total quality management in higher education. Quality and Quantity, 47(4), 1883-1904. https://doi.org/10.1007/s11135-011-9632-9

7. Baig, S. A., Abrar, M., Ali, A., \& Ahmad, M. (2015). Implementation of TQM on higher education in Pakistan. Quality \& Quantity, 49(1), 51-56. https://doi.org/10.1007/s11135-013-9973-7.

8. Banerjee, N., \& Sah, S. (2012). A comparative study of customers' perceptions of service quality dimensions between public \& private banks in India. International Journal of Business Administration, 3(5), 33-44. https://doi.org/10.5430/ijba.v3n5p33

9. Batarfi, S., \& Attia, A. (2021). Measuring the effect of quality management practices on company financial performance - A case study on IKEA. PalArch's Journal of Archaeology of Egypt/Egyptology, 18(15), 113-121. https://doi.org/10.1002/phvs.202170320

10. Ben, K., Zouari, S., \& Taktak, N. B., (2014). Ownership structure and financial performance in Islamic banks: Does bank ownership matter? International Journal of Islamic and Middle Eastern Finance and Management, 7 (2), 146 - 160. https://doi.org/10.1108/IMEFM-01-2013-0002

11. Chaudhry, N. I., Awan, M. U., Bilal, A., \& Ali, M. A. (2018). Impact of TQM on organizational performance: the mediating role of business innovativeness and learning capability. Journal of Quality and Technology Management, 15 (1), 01-36.

12. Cohen, P., West, S. G., \& Aiken, L. S. (2014). Applied multiple regression/correlation analysis for the behavioral sciences. Psychology Press. https://doi.org/10.4324/9781410606266

13. Dieste, M., Panizzolo, R., \& Garza-Reyes, J. A. (2021). A systematic literature review regarding the influence of lean manufacturing on firms' financial performance. Journal of Manufacturing Technology Management. https://doi.org/10.1108/JMTM-08-2020-0304

14. Feng, J., Prajogo, D. I., Tan, K. C., \& Sohal, A. S. (2006). The impact of TQM practices on performance: a comparative study between Australian and Singaporean organizations. European Journal of Innovation Management, 9 (3), 269-278. https://doi.org/10.1108/14601060610678149

15. Fowler, F. J. (2013). Survey research methods. SAGE Publications.

16. Garcia-Bernal, J., \& Ramirez-Aleson, M. (2017). Why and how TQM leads to performance improvements. The Quality Management Journal, 22(3), 23-37. https://doi.org/10.1080/10686967.2015.11918439

17. Gupta, V. P., \& Agarwal, P. K. (2013). Comparative study of customer satisfaction in public and private banks in India; A case study of meert region of U.P. Global Journal of Business Management, 7(1), 16-26.

18. Hanaysha, J. R., Abdullah, H. H., \& Warokka, A. (2011). Service quality and students' satisfaction at higher learning institutions: The competing dimensions of Malaysian Universities' competitiveness. Journal of Southeast Asian Research, 4(1),: 1-10. https://doi.org/10.5171/2011.855931

19. Karim, R. A., \& Chowdhury, T. (2014). Customer satisfaction on service quality in private commercial banking sector in Bangladesh. British Journal of Marketing Studies, 2(2), 1-11.

20. Kashif, M., Suzana , S., Shukran, W., \& Rehman , M. A. (2015). Customer satisfaction and loyalty in Malaysian Islamic banks: a PAKSERV investigation. International Journal of Bank Marketing, 33(1), 23-40. https://doi.org/10.1108/IJBM-08-2013-0084

21. Khan, M. M., \& Fasih, M. (2014). Impact of service quality on customer satisfaction and customer loyalty: Evidence from banking sector. Pakistan Journal of Commerce and Social Sciences, 8(2), 331-354.

22. Khan, M. M., Ahmed, I., \& Nawaz, M. M. (2011). Student's perspective of service quality in higher learning institutions: An evidence based approach. International Journal of Business and Social Science, 2(11), 159-164.

23. Kull, T. J., \& Wacker, J. G. (2010). Quality management effectiveness in Asia: The influence of culture. Journal of Ooperations mManagement, 28(3), 223-239. https://doi.org/10.1016/j.jom.2009.11.003

24. Martínez-Costa, M., Choi, T. Y., Martínez, J. A., \& Martínez-Lorente, A. R. (2009). ISO 9000/1994, ISO 9001/2000 and TQM: The performance debate revisited. Journal of Operations Management, 27(6), 495-511. https://doi.org/10.1016/j.jom.2009.04.002 
25. Mohammad, B., Muzaffar, A., \& Hussain, S. (2011). Customer satisfaction with service quality in conventional banking in Pakistan: The case of Faisalabad. International Journal of Marketing Studies, 3(4), 165-174. https://doi.org/10.5539/ijms.v3n4p165

26. Nicolau, J. L., \& Sellers, R. (2010). The quality of quality awards: diminishing information asymmetries in a hotel chain. Journal of Business Research, 63(8), 832-839. https://doi.org/10.1016/j.jbusres.2009.06.009

27. Ozretic-Dosen, D., \& Zizak, I. (2015). Measuring the quality of banking services targeting student population. EuroMed Journal of Business, 10(1), 98-117. https://doi.org/10.1108/EMJB-01-2014-0002

28. Qasrawi, B. T., Almahamid, S. M., \& Qasrawi, S. T (2017). The impact of TQM practices and KM processes on organizational performance: An empirical investigation. International Journal of Quality and Reliability Management, 34(7), 1034-1055. https://doi.org/10.1108/IJQRM-11-2015-0160

29. Raphael, G., \& Man, W. (2013). Integrating financial and non-financial measures to measure the performance of commercial banks: Evidence from Tanzania. Research Journal of Finance and Accounting, 4(3), 1-11.

30. Santos, C. R., Contreras, A. M., Faúndez, C., \& Palomo-Vélez, G. F. (2015). Adapting the SERVQUAL model to a physical activity break satisfaction scale. International Journal of Workplace Health Management, 8 (1), 34 -45. https://doi.org/10.1108/IJWHM-05-2014-0018

31. Saunders., M., Lewis., P., \& Thornhill., A. (2012). Research methods for business students. Pearson Higher Ed.

32. Senthilkumar, N., \& Arulraj, A. (2011). SQM-HEI-determination of service quality measurement of higher education in India. Journal of Modelling in Management, 6(1), 60-78. https://doi.org/10.1108/17 465661111112502

33. Shafiq, M., Lasrado, F., \& Hafeez, K. (2017). The effect of TQM on organizational performance: Empirical evidence from the textile sector of a developing country using SEM. Total Quality Management \& Business Excellence, 30(1-2), 31-522. https://doi.org/10.1080/14783363.2017.1283211

34. Shahin, A., Jamkhaneh, A. B., Zahra, S., \& Cheryani, H. (2014). EFQM Qual: Evaluating the implementation of the European quality award based on the concepts of model of service quality gaps and SERVQUAL approach. Measuring Business Excellence, 18 (3), 38-56. https://doi.org/10.1108/MBE-12-2012-0057

35. Sila, I. (2018) Investigating changes in TQM's effects on corporate social performance and financial performance over time. Total Quality Management \& Business Excellence, 31(1-2), 210-229. https://doi.org/10.1080/14783363.2018.1458609

36. Sila, I., \& Ebrahimpour, M. (2005). Critical linkages among TQM factors and business results. International Journal of Operations \& Production Management, 25(11), 1123-1155. https://doi.org/10.110 $\underline{8 / 01443570510626925}$

37. Singh, V., Kumar, A., \& Singh, T (2018). Impact of TQM on organizational performance: The case of Indian manufacturing and service industry Operations. Research Perspectives, 5, 199-217. https://doi.org/10.101 6/j.orp.2018.07.004

38. Sit, W. Y., Ooi, K. B., Loke, S. P., \& Han, G. T. W. (2010). TQM and service quality: A survey of commercial banking industry in Malaysia. International Journal of Services, Economics and Management, 3(1), 78-91. https://doi.org/10.1504/IJSEM.2011.037179

39. Woods, M. \& Miles, M. P. (2014). Collaborative development of enterprise policy: A process model for developing evidence-based policy recommendations using community focused strategic conversations and SERVQUAL. International Journal of Public Sector Management, 27(3), 174-189. https://doi.org/10.1108 /IJPSM-09-2012-0121

40. Yas, H., Alsaud, A., Almaghrabi, H., Almaghrabi, A., \& Othman, B. (2021). The effects of TQM practices on performance of organizations: A case of selected manufacturing industries. Saudi Arabia. Management Science Letters, 11(2), 503-510. https://doi.org/10.5267/j.msl.2020.9.017

41. Zabadi, A. M. A. (2013). Implementing total quality management (TQM) on the higher education institutions: A conceptual model. Journal of Finance and Economics, 1(1), 42-60. https://doi.org/10.12735/jfe.v1i1p42

42. Zhang, M., Xie, Y., Huang, L., \& He, Z. (2014). Service quality evaluation of car rental industry in China. International Journal of Quality \& Reliability Management, 31(1), 82-102. https://doi.org/10.1108/IJQRM-112012-0146

43. Zwain, A. A. A., Lim, K. T., Othman, S. N. (2017). TQM and academic performance in Iraqi HEIs: Associations and mediating effect of KM. TQM Journal, 29(2), 357-368. https://doi.org/10.1108/TQM-082013-0096 